\title{
Optimalisasi Profitabilitas Perusahaan Farmasi melalui Rasio Likuiditas pada PT. Kimia Farma Pekanbaru
}

\author{
MURNAWATI \\ Jurusan Manajemen Fakultas Ekonomi \\ Universitas Lancang Kuning \\ Jl. Yos Sudarso KM. 08 Rumbai - Pekanbaru
}

\begin{abstract}
One important factor to measure the liquidity of a company then used Carrent Variable Ratio of dividing current assets by current liabilities Quick ratio is current assets minus persidiaan divided by current liabilities and inventories to Turn Over ie sales divided by inventory, and to measure the profitability of a companies use Return on Assets (ROA) is net profit after tax in the total asset.Berdasarkan background above problem, then the problem can be formulated as follows whether likuididas conditions significantly affect the level of profitability at PT. Kimia Farma Pekanbaru.Tujuan of research to obtain empirical evidence about whether liquidity significantly affect the level of profitability at PT. Kimia Farma Pekanbau The next test is to compare the profitability value (significance F) and $a=0$, 05. SPSS printout of the results shows the probability value of 0.005 which is smaller than 0.05. so Ho is rejected and $\mathrm{Ha}$ accepted. This means that variable liquidity conditions significantly affect the condition profitabilitas.Sedangkan when in partial test, print out computer (attached) shows the results of a data analyst and partial hypothesis testing that variable curent Ratio indicates the level of significance of 0.005 which means that small of $a=0.05$, so ho rejected and Ha accepted this means the current ratio variable effect on the level of profitability at PT Kimia Farma.
\end{abstract}

Keywords: Likwiditas dan Profitabilitas

Tujuan didirikanya suatu perusahaan atau unit usaha adalah untuk memperoleh laba dan keuntungan yang maksimal, di samping tujuan social lainya, seperti membuka lapangan kerja dan lain lain. Untuk memperole laba yang maksimal, bermacam usaha dapat di tempuh oleh pihak manajemen seperti dengan meningkatkan volume penjualan, melakukan efesiensi biaya, meniadakan dana yang menganggur dan lain - lain. Masing - masing perusahaan juga di tuntut untuk dapat mengelola likuiditasnya dengan baik dan tepat agar resiko rugi serta menurunya kepercayaan masyarakat dapat di hindari. Masalah utama yang sering di hadapi oleh perusahaan dalam pengelola sisa aktiva dan pasiva perusahaan adalah memecahkan konflik antara likuiditas dan keamanan di satu pihak dengan kemampuan meningkatkan laba di pihak lain (Profitabilitas ).

Perusahan dalam usanya untuk meningkatkan profitabilitas di tuntut untuk mengalokasikan dananya kepada kegiatan usaha yangt menguntungkan, seperti sektor perkreditan, surat - surat berharga, perdagangan valuta asing dan penanaman dana pada nonearning assets seperti kas, gedung, peralatan kantor dan sebagainya, tetapi sementara itu harus pula memperhatikan keamanan aktiva tersebut dan kemungkinan kebutuhan likuiditasnya. Dana merupakan factor yang paling dominan dalam kegiatan perusahaan.Dana dapat bersumber dari pinjaman pihak luar, ataupun dari pihak perusahan. Setiap sumber kepemilikan dana akan memberikan konsekuensi terhadap kebijakan manajemen perusahaan maupunkinerja usahanya. Oleh karena setiap kewajiban hamper seluruh dibayar dengan kas, maka dilihat dari kepentingan likuiditas sudah barang tentu alat likuid seperti uang kas dan rekening merupakan aktiva paling utama.

Kondisi likuiditas yang baik dapat menunjang pencapian tujuan perusahaan dalam memperoleh laba dan pengembangan usaha di masa yang akan datang tidak dapat terjadi begitu saja tampa adanya pengelolaan yang baik oleh manajemen. 
Kondisi tersubut harus di ciptakan oleh manajemen dalam tugas dan fungsinya dalam keuangan yaitu penentuan alokasi terbaik dari aktiva tetap dan aktiva lainya serta alokasi antara hutang lancar dengan modal jangka panjang. Kondisi keuangan suatu perusahan tergambar dalam neraca yang disajikan dalam proses akutansi pada perusahaan tersebut. Dalam neraca tersebut tergambar besarnya alokasi dan dana untuk aktiva lancar, aktiva tetap dan aktiva lainya serta tergambar sumber pembiayaan perusahaan yang berasal dari hutang jangka pendek, hutang jangka panjang dan modal sendiri. Isi dari neraca ini belum sepenuhnya dapat memberi informasi yang akurat tentang baik dan buruknya kondisi keuangan perusahaan secara keseluruhan.Sehingga untuk memperoleh informasi yang lebih akurat dan terperici tentang kondisi keuangan perusahaan perlu dilakukan analisis lebih lanjut terhadap laporan keuangan perusahaan untuk dapat mengetahui kondisi likuiditas, solvabilitas dan profitabilitas dari operasi perusahaan.

Likuiditas adalah: Merupakan suatu indikator mengenai kemampuan perusahaan untuk membayar semua kewajiban finansial jangka pendek pada saat jatuh tempo dengan menggunakan aktiva lancar yang tersedia, (Lukman Syamsuddin;2007;41). Dalam Meithi,2011 Melakukan penelitian tentang Pengaruh Likwiditas dan Propabilitas terhadap Harga saham Perusahaan Manufaktur Secara parsial, likuiditas yang diukur dengan Current Ratio tidak berpengaruh signifikan terhadap harga saham perusahaan manufaktur Secara parsial, profitabilitas yang diukur dengan Earnings Per Share (EPS) tidak berpengaruh signifikan terhadap harga saham perusahaan manufaktur. Secara simultan, likuiditas dan profitabilitas berpengaruh signifikan terhadap harga saham perusahaan manufaktur.

Rasio likuiditas adalah: menggambarkan kemampuan perusahaan untuk menyelesaikan kewajiban jangka pendeknya. Rasio rasio ini dapat di hitung melalui sumber informasi tentang modal kerja yaitu pos - pos aktiva lancar dan hutang lancar, (Sofyan Syafri Harahap;2002; 301). Pengertian Profitabilitas adalah : Memaksimumkan keuntungan selalu ada pertukaran dengan risiko. Semakin besar resiko yang di hadapi, akan semangkin besar pula keuntungan yang diharapkan, (Budi Rahardjo;2007;10) Sedangkan menurut Brigham dan Houston (2006;107).adalah : Hasil akhir dari sejumlah kebijakan dan keputusan yang dilakukan oleh perusahaan. Rasio - rasio yang telah di bahas sejauh ini dapat memberikan petunjuk - petunjuk yang berguna dalam menilai keefektivan dari operasi sebuah perusahaan, tetapi rasio profitabilitas akan menunjukan kombinasi efek dari likuiditas, manajemen aktiva, dan hutang pada hasil - hasil operasi, Sebagaimana telah dikemukakan sebelumnya dalam rangka memperoleh laba kondisi likuiditas merupakan kondisi yang paling penting. Apabila suatu perusahaan tidak mampu memenuhi kewajibanya dalam jangka pendek, berarti perusahaan tidak dapat memperoleh kesempatan untuk mendapatkan laba (Profit) atau pengembangan diri dalam jangka panjang, sebagai contoh jika perusahaan tidak segera menyediakan bahan baku maka aktivitas operasional perusahaan akan terhenti, hal ini tentu berdampak terhadap berkurangnya penjualan,. Jika ini terjadi maka perusahaan akan mengalami kerugian. Contoh lainya adalah jika perusahaan tidak segera atau menunda - nunda pembayaran gaji karyawan dan buruh, hal ini akan membuat karyawan dan buruh mogok kerja, jika ini terjadi maka perusahaan akan mengalami kerugian.

Salah satu faktor penting untuk mengukur likuiditas suatu perusahaan maka digunakan variabel Carren Rasio yaitu pembagian aktiva lancar dengaan hutang lancar, Quick Rasio yaitu aktiva lancar dikurangi persediaan di bagi dengan hutang lancar danInventori tro Turn Over yaitu penjualan di bagi dengan persediaan, dan untuk mengukur Profitabilitas suatu perusahaan digunakan Return On Asset ( ROA ) yaitu laba bersih setelah pajak di 
bagi total asset. Berdasarkan Uraian di atas maka peneliti mencoba untuk menguji apakah Apakah likuiditas berpengaruh terhadap tingkat profitabilitas pada PT Kimia Farma Pekanbaru

Likuiditas adalah menggambarkan kemampuan perusahaan untuk menyelesaikan kemampuan jangka pendeknya. Rasio rasio ini dapat di hitung melalui sumber informasi tentang modal kerja yaitu pos pos aktiva lancar dan hutang lancar, (Sofyan Syafri Harahap;2002; 301). Rasio Lancar (Current Ratio) merupakan rasio untuk mengukur kemampuan perusahaan dalam membayar kewajiban jangka pendek atau hutang yang segera jatuh tempo pada saat ditagih secara keseluruhan. Dengan kata lain, seberapa banyak aktiva lancar yang tersedia untuk menutupi kewajiban jangka pendek yang segera jatuh tempo. Untuk menghitung Current Ratio dapat menggunakan rumus :

\section{Current}

$=\frac{\text { Aktiva Lancar (Current Assets ) }}{\text { Hutang Lancar (Current Liability ) }}$

merupakan perbandingan antara aktiva lancar (kecualipersediaan) dengan utang lancar. Rasio ini merupakan rasio likuiditas yang lebih ketat daripada current ratio. Persediaan di anggap aktiva lancar kurang likuid, sebab harus melalui dua tahap untuk menjadi kas ( persediaan di jual menjadi piutang, piutang di kumpulkan, baru menjadi kas). (Abdul Halim dan sarwoko;2010;54)

Rumus untuk mencari rasio cepat dapat menggunakan :

Quick Ratio
Aktiva Lancar (Current Assets) - Inventory

Hutang Lancar (Current Liability)

Profitabilitas

adalah

Memaksimumkan keuntungan selalu ada pertukaran dengan risiko. Semakin besar resiko yang di hadapi, akan semangkin besar pula keuntungan yang diharapkan, (Budi Rahardjo;2007;10). Salah satu cara mengukur profitabilitas atau rentabilitas perusahaan untuk mengetahui kemampuan suatu perusahaan dalam menghasilkan laba dibandingkan dengan aset yang dimiliki oleh perusahaan. Return on Asset adalah rasio profitabilitas yang menunjukkan perbandingan antara laba setelah pajak dengan total aset bank, rasio ini menunjukkan tingkat efisiensi pengelolaan aset yang dilakukan oleh bank yang bersangkutan.

Untuk menghitung ROA dapat menggunakan rumus :

ROA = Laba Setelah Pajak (Earning After Tax)

Total Aset

Menunjukan kemampuan perusahaan dalam menghasilkan laba atas aktiva yang di pergunakan, (Farah Margaretha;2005; 21). Berdasarkan rumus, dapat dijelaskan bahwa ROA merupakan perbandingan antara laba setelah pajak terhadap total aset. Rasio ini berfungsi untuk melihat sejauh mana investasi yang telah ditanamkan mampu memberikan pengembalian keuntungan sesuai dengan yang diharapkan. Return On Equity adalah rasio profitabilitas yang menunjukkan perbandingan antara laba setelah pajak dengan modal bank, rasio ini menunjukkan tingkat persentase yang dapat dihasilkan. Fungsi ROE adalah untuk mengetahui kemampuan bank dalam menghasilkan laba bersih melalui penggunaan modal sendiri, untuk mengukur kemampuan manajemen bank dalam mengelola capital yang ada untuk mendapatkan net income.

Untuk menghitung ROE, dapat menggunakan rumus :

$\mathrm{ROE}=$

Laba Setelah Pajak (Earning After Tax) Modal (Shareholders' Equity)

Berdasarkan teori di atas dapat disimpulkan yang mempengaruhi Likuiditas adalah variabel yang ada pada laporan keuangan yaitu dilihat dari aktiva lancar yang tersedia untuk menutupi kewajiban jangka pendek yang segera jatuh tempo. Yang mempengaruhi Profitabilitas adalah variabel yang ada pada laporan keuangan dilihat dari total aktiva, dan besarnya 
keuntungan yang diperoleh oleh suatu perusahaan.

\section{METODE}

Data yang digunakan dalam penelitian ini adalah data kuantitatif, yaitu data berupa angka - angka yang menunjukan jumlah atau banyaknya sesuatu, yaitu laporan keuangan perusahaan (neraca dan laporan laba rugi). Adapun sumber data dalam penelititan ini berupa laporan keuangan yang diperoleh dari situs internet (www.idx.co.id). Teknik pegumpulan data dilakukan dengan cara dokumentasi, dalam menganalisis data penulis menggunakan model regresi

\section{HASIL}

Analisis korelasi digunakan untuk mengukur besarnya hubungan antara dua variabel atau antar set variabel. Analisis korelasi yang di gunakan adalah:

$$
\text { Koefisien determinasi atau }
$$
disimbolkan dengan $\mathrm{R}$ yang menunjukan hubungan yang erat antara variabel terikat dengan variabel bebas secara bersama sama. Sedangkan koefisien berganda disimbolkan R2merupakan kesesuaian garis linier berganda terhadap data.

\begin{tabular}{|l|l|l|l|}
\hline $\mathrm{R}$ & $\begin{array}{l}\mathrm{R} \\
\text { Square }\end{array}$ & $\begin{array}{l}\text { Adjusted } \\
\text { Square }\end{array}$ & $\begin{array}{l}\text { Std. Error of the } \\
\text { Estimate }\end{array}$ \\
\hline $.975^{\mathrm{a}}$ & .950 & .933 & 15486.53163 \\
\hline
\end{tabular}

Berdasarkan tabel di atas, bahwa variabel bebas yaitu ( $X$ ) mempunyai hubungan dengan variabel ( $\mathrm{Y}$ ) hal ini membuktikan melalui nilai Koefisien korelasi ( $\mathrm{R}$ ) sebesar 0.975. Pada tabel tersebut telah diketahui bahwa koefisien determinasi( R2)sebesar 0,950.

Koefisien korelasi (r) digunakan untuk mengukur derajat dua variabel dan untuk mengetahui dua arah variabel adala 0 sampai dengan \pm 1 . Apabila nilai $r=-1$ artinya korelasi negatif , $r=0$ artinya tidak ada korelasi, dan $r=1$ artinya korelasi sangat kuat. Sedangkan arti r akan di konsultasikan dengan korelasi nilai $r$.
Dari nilai koefisien korelasi variabel dengan sig. Maka dapat kita ketahui bahwa: $\mathrm{r}=0.968 \rightarrow \mathrm{r} 2=(0,936) 2=0.876$ atau $87.6 \%$. Artinya: besarnya pengaruh likuiditas terhadap profitabilitas adalah $87.6 \%$ sedangkan sisanya $12.4 \%$ dipengaruhi oleh faktor lain. Dari analisis regresi akan diketahui ada tidaknya pengaruh dari variabel bebas, baik secara terpisah maupun secara bersama - sama. Analisis Regresi dapat dilakukan dengan cara sebagai berikut:

\begin{tabular}{|c|c|c|c|c|c|}
\hline \multirow[b]{2}{*}{ Model } & \multicolumn{2}{|c|}{$\begin{array}{l}\text { Unstandardized } \\
\text { Coefficients }\end{array}$} & \multirow{2}{*}{$\begin{array}{l}\text { Standardize } \\
\text { d } \\
\text { Coefficients } \\
\text { Beta }\end{array}$} & \multirow[b]{2}{*}{$\mathrm{t}$} & \multirow[b]{2}{*}{ Sig. } \\
\hline & B & Std. Error & & & \\
\hline 1 (Constant) & $\begin{array}{l}- \\
374449.57 \\
6\end{array}$ & $\begin{array}{l}65436.59 \\
3\end{array}$ & & $\begin{array}{l}- \\
5.72 \\
2\end{array}$ & $\begin{array}{l}.01 \\
1\end{array}$ \\
\hline $\begin{array}{l}\text { Current_Rati } \\
\text { o }\end{array}$ & .670 & .089 & .975 & $\begin{array}{l}7.55 \\
2\end{array}$ & $\begin{array}{l}.00 \\
5\end{array}$ \\
\hline
\end{tabular}

a. Dependent Variable: Return_On_Asset

Berdasarkan tabel di atas hasil analisis regresi, maka persamaan regresi linier yang di hasilkan adalah:

$$
\begin{aligned}
& Y=a+b x \\
& Y=-374449.576+0.670
\end{aligned}
$$

Maka setiap ada perubahan atau kenaikan Current Rasio sebesar satu satuan maka akan merasakan kenaikan ROA sebesar 6.7.Misalnya Current Rasio naik $1 \%$ maka ROA akan memjadi $6.70 \%$. Uji regresi persial digunakan untuk mengetahui masing - masing variabel bebas terhadap variabel terikat dengan melihat signifikan dari nilai $\mathrm{t}$ ( $\mathrm{t}$-value). Pengambilan keputusan berdasarkan perbandingan nilai $t$ hitungdengant tabel jikat hitung >t tabel maka variabel bebas memiliki pengaruh positif terhadap variabel terikat. Sedangkan untuk melihat besarnya pengaruh, digunakan angka Beta atau Standardized Coeffecient.

Untuk menghitung besar angkat $\mathrm{t}$ tabel dengan ketentuan sebagai berikut:

Taraf signifikan 0,05 dengan derajat kebebasan ( DK ) dengan ketentuan ( DK ): $\mathrm{DK}=\mathrm{n}-2$, atau $\mathrm{DK}=5-2=3$ dengan tingkat kepercayaan 95\% pada level $\mathrm{a}=$ 0,05 adalah 2,015 . Nilai thitung $=7.552$ 
Asumsi:

Ho diterima, $\mathrm{H} 1$ ditolak, jika $\mathrm{t}$ hitung $<\mathrm{t}$ tabel Ho ditolak, H1 diterima, jika t hitung $<\mathrm{t}$ tabel Kesimpulan:

Karena nilai berarti $\mathrm{t}$ hitung $=7.552>\mathrm{t}$ tabel 2,015, maka Ho ditolak dan H1 diterima. Artinya terdapat pengaruh yang signifikan antara Likuiditas dan Profitabilitas. Berarti kenaikan atau penurunan Likuiditas memiliki pengaruh yang signifikan terhadap Profitabilitas.

\section{PEMBAHASAN}

Dari hasil di atas, maka dapat diketahui bahwa PT Kimia Farma, adalah perusahaan yang bergerak di bidang farmasi, dimana dalam skripsi ini penulis melakukan penelitian dengan mengambil data laporan keuangan mulai dari tahun 2006 - 2011. Berdasarkan hasil analisis data dan pengujian hipotesis yang dilakukan bahwa kondisis likuiditas yang terdiri dari current ratio, berpengaruh secara signifikan terhadap tingkat profitabilitas pada PT Kimia Farma Pekanbaru. Berdasarkan hasil analisis data dan pengujian hipotesis secara parsial bahwa variabel Current Ratio menunjikan tingkat significance sebesar 0, 005 yang berarti kecil dari $\alpha=0,05$ jadi Ho ditolak dan Ha diterima ini berarti variabel current ratio berpengaruh terhadap tingkat profitabilitas pada PT Kimia Farma.

Masalah Likuiditas merupakan masalah yang sangat penting dan erat kaitanya dengan kepercayaan mitra kerja, masyarakat, dan pemerintah, serta menentukan kemampuan perusahaan untuk bertahan hidup atau beroperasi. Karena kondisi Likuiditas yang terdiri dari variabel Current Ratio, Quick Ratio berpengaruh terhadap tingkat profitabilitas, maka di sarankan kepada pihak manajemen perusahaan untuk memfokuskan perhatian pada kondisi likuiditas tersebut. Tetapi juga memperhatikan variabel - variabel lainya yang tidak termasuk dalam penelitian ini dalam upaya meningkatkan profitabilitas pada PT Kimia Farma.

\section{SIMPULAN}

Dari uraian di atas, maka dapat disimpulkan bahwa bahwa kondisis likuiditas yang terdiri dari current ratio, berpengaruh secara signifikan terhadap tingkat profitabilitas pada PT Kimia Farma Pekanbaru.

\section{DAFTAR RUJUKAN}

Abdul Halim, Sarwoko, 2010, Manajemen Keuangan, Edisi Kedua, Cetakan Keempat, BPFE - Yogyakarta.

Brigham \& Houston, 2006, Dasar - Dasar Manajemen Keuangan, Edisi Sepuluh, Buku Satu, Salemba Empat.

Budi Rahardjo, 2007, Keuangan Akutansi Untuk Manajer Non Keuangan, Edisi Pertama, Cetakan Pertama, Candi Gebang Permai.

Dwi Prastowo,Rifka Juliaty, 2002, Analisis Laporan Keuangan Konsep Dan Aplikasi.Edisi yang Diperbaruhi, Cetakan Kedua, AMP YKPN.

Farah Margharetha, 2005, Teori Dan Aplikasi Manajemen Keuangan, Edisi Pertama, PT Grasindo.

Fachmi Basyaib, 2000, Keuangan Perusahaan Pemodalan Menggunakan Microsoft Exel,Edisi Satu, Cetakan Satu, Kencana Prenada Media Group.

Harmono, 2009, Manajemen Keuangan Berbasis Balanced Scorecard Pendekata Teori, Kasus, Dan Riset Bisnis. Edisi Pertama, PT Bumi Aksara.

Henry Simamora, 2000, Akutansi Basis Pengambilan Keputusan Bisnis, Edisi Pertama, Salemba Empat Grend Wijaya Center. 
James C. Van Horne, John M. Wachowicz, 2005, Prinsip - Prinsip Manajemen Keuangan,Edisi Duabelas, Buku Satu, Salemba Empat.

Kasmir, 2010, Pengantar Manajemen Keuangan, Edisi Pertama, Cetakan Kesatu, Kencana Prenada Media Group.

Lukman Syamsuddin, 2007, Manajemen Keuangan Perusahaan, Edisi Baru, PT Raja Grafindo Persada.

Mamduh M. Hanafi, Abdul Halim, 2000, Analisis laporan keuangan, Edisi yan Diperbaruhi, Cetakan Kedua, AMP YKPN.

Meithi, 2011, Pengaruh Likwiditas dan Profitabilitas terhadap harga saham perusahaan Manufaktur Jurnal Bisnis Manajemen \&Ekonomi. Vulume10 no. 2 Mei 2011 ISSN 1693-8305
S.Munawir, 2002, Analisis informasi Keuangan. Edisi Pertama, LIBERTY Yogyakarta.

Sofyan Syafri Harahap, 2002, Analisis Kritis Atas Laporan Keuangan, Cetakan Ketiga, PT Raja Grafindo Persada.

http://idx.co.id

http:/www.kimiafarma.co.id 